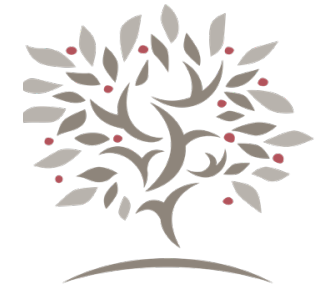

ARTICLE

\title{
How Online Learning May Disadvantage Students from Some Cultures and What to Do About It in the Theology Classroom
}

\author{
Glenn Fluegge \\ Concordia University Irvine
}

\begin{abstract}
A B S TRACT
Online learning is not a culturally neutral form of learning, but, like any educational approach, has been and continues to be shaped by significant sociohistorical and cultural forces. Not just what is taught, but also the means by which it is taught-the technological medium of online education-is influenced by culture and should be adapted and adjusted accordingly. With illustrations and examples pulled from the author's experience of teaching theology to students from throughout Africa and the United States, this essay explores four "dimensions of culture"-collectivist versus individualist, high versus low power distance, high-versus low-context, and oral versus literate preference-and analyzes how students from more collectivistic, high power distance, high-context, and oral preference societies may be disadvantaged by commonly used and accepted approaches to online learning. It then offers some practical suggestions for adjusting online theological education to be more culturally responsive.
\end{abstract}

\section{KEYWORDS}

online learning, theological education, culture, collectivism, power distance, high-context, orality

\section{Introduction}

Online learning provokes all sorts of emotions and reactions, ranging from wholehearted love to utter contempt (see, e.g., Dynarski 2018; Arkorful and Abaidoo 2015; Horodyskyj et al. 2018; Bettinger and Loeb 2017; Fain 2019) and, from my experience, all the more when applied to theology and particularly pastoral training. So, let me begin with a caveat: No matter where you fall on the spectrum of responses to online theological education, I am on your side. To underscore this point, let me share a bit of my own background. I was a residential student for all four years of my undergraduate studies as well as for three years of graduate seminary studies and I have a deep appreciation for my time as part of those two communities. For over ten years, I served as director and then academic dean of an international residential seminary in Togo, West Africa where every year, at considerable expense, we brought students (along with their families, if possible) to our campus to train them as pastors. After that, I taught for 
three years at an international residential seminary in South Africa. However, I also earned an entire master's degree in education, without ever stepping foot on their campus or seeing any of my professors or fellow students. I went through a two-year comprehensive missionary training program taught via distance by mentors in the United States while I was deployed in Togo. And currently, I head up the Cross-cultural Ministry Center (CMC), a graduate-level seminary program at a liberal arts university that uses a hybrid approach ${ }^{1}$ to online learning to offer pastoral and missionary training to students from our surrounding community in southern California and as far away as Hawaii, Minnesota, Mexico, and even China. So again, no matter where you fall on this issue, I am on your side.

My intention in this essay is not to make a value judgment against or for online learning. The truth is that not only does online learning greatly increase our opportunity as professors to reach more students, but research has shown it to be quite effective, especially when done correctly. In any case, it is a reality and almost all of us have been or will be engaged in some form of it throughout our careers. Rather, my intention is to explore the very real existence of one aspect of online learning that, I believe, is often unintentionally overlooked or conveniently ignored-its cultural dimension.

I am intrigued by culture partly because I spent so many years working in an international setting far from my "home culture." "Once a missionary, always a missionary," as they say, so I ask the reader's indulgence as I bring in some admittedly anecdotal observations from my time living and working in two African countries, as well as the United States. Admittedly, the cultural disparities between the Moba people living in the remote village of Lokpano, Togo and the south Orange County suburban residents of Irvine, California may be much greater than those we might encounter in our average classroom (or not, depending on the classroom!). Nonetheless, some lessons learned from more apparent cultural differences on another continent are applicable to our classroom experiences here in the United States. At the very least, seeing these cultural differences will be an impetus for reflecting on how similar, yet perhaps less apparent, cultural differences and influences exist in our own classrooms.

My working thesis here is this: Not just what is taught, but also the means by which it is taught is influenced by culture and can be adapted accordingly. In other words, the technological medium of education-online learning-is as culturally influenced as the content itself, and therefore, it too should be adjusted to account for cultural differences.

\section{The Problem of the Hiddenness of Culture}

This thesis is not as self-evident as it might seem at first. First, despite some efforts over the last several years, there remains a dearth of in-depth quality research on this topic (see earlier complaint by Edmundson [2007]). The rising popularity of distance education via online learning has been linked to the rising popularity of the World Wide Web and, despite very rapid advances, it is still a rather recent phenomenon. Educational research in the field of online learning and culture is still in its beginning stages.

However, there is another reason why it is not so simple. Distance learning emerged originally from a Euro-American Western cultural context (for a detailed discussion, see Fluegge [2010]) and that context continues to influence online learning in profound ways. ${ }^{2}$ In addition, until recently, most of the research on distance and online learning has come from that same Western context and has tended to assume that the medium of distance learning is generally culturally neutral. The underlying problem is that one's own culture is surprisingly difficult to detect. Why is that?

The late Paul Hiebert, a well-known Christian anthropologist, defined culture as "the more or less integrated systems of ideas, feelings, and values, and their associated patterns of behavior and products shared by a group of people who organize and regulate what they think, feel, and do" $(1985,30)$. The difficulty is that the deeper levels of culture-those

\footnotetext{
1 We offer synchronous live interactive courses during the year and face-to-face three-week intensives during the summer. See our underlying rationale for this pedagogical approach below.

2 I view online learning as a subset or type of the more broadly understood category of distance learning. Although this essay focuses especially on online learning, I do occasionally refer to the broader category of distance education/learning to include other earlier modes of learning such as written correspondence or self-guided workbooks. Although there are obvious differences between older kinds of distance learning and today's online learning, there are also underlying similarities, including the sociocultural context that birthed them.
}

188 2021; 2:1 187-202 The Wabash Center Journal on Teaching

This work is licensed under a Creative Commons Attribution-NonCommercial 4.0 International License 
parts of culture that are particularly influential in organizing and shaping the way a person thinks-are not what one sees on the surface. What one immediately sees when encountering a different culture are simply the by-products of those very systems of ideas, feelings, and values that lay at the very core of a person. Anthropologist and long-time missionary Eugene Bunkowske $(2002,2012)$ created the "cultural onion" as a way of viewing and understanding culture as made up of layers, similar to those of an onion. The outside layers of culture-artifacts and behaviors-are immediately apparent and accessible. He calls these the "actualizing" layers of culture. Although they are what we first perceive during an initial cultural encounter, these outside layers are simply what one might call "surface symptoms" of much deeper layers of culture, such as feelings, values, and beliefs. ${ }^{3}$ Bunkowske labels these the "evaluating" layers of culture. They are what enable us to make decisions about what is good, true, and enjoyable in life. They are embedded so deeply in our consciousness that we very often do not know or are not able to explain why we consider this good or deem that false or find this enjoyable rather than that. Nevertheless, even these layers are not as deeply buried, implicit, and unconscious as the "foundational" layers of culture. According to Bunkowske, a person's worldview and ultimate allegiance make up the core of culture. These layers provide the "perceptual basis and the mental mapping for the other levels of culture" $(2002,3)$. They cause, mold, and shape the evaluative conclusions regarding one's beliefs, values, and feelings, which in turn are actualized in day-today life through collecting certain things and doing certain activities.

Bunkowske's model of culture draws attention to the fact that when it comes to culture what one sees on the surface is not all there is. So, lowering myself, averting my eyes, and supporting my right arm with my left hand as I shake an elder's hand in northern Togo would be considered normal practice. This behavior (on the actualizing level) reflects a much deeper feeling of respect for elders and their value among the Moba people (on the evaluating level). Moreover, the underlying worldview (on the foundational level) that considers elders, similarly to ancestors, as liaisons with Yendu, the creator God, may also be shaping, influencing, and contributing to these outward visible behaviors. Additionally, in oral preference societies, wisdom and knowledge are not bound in books but must be preserved and passed on by the elders. This oral-aural preference is an integral part of worldview (again, on the foundational level of culture) that would seem to give inherent value to elders (cf. Cole and Scribner 1974, 125).

What I still find surprising is that although I could, at least to a certain extent, detect and analyze cultural influences among the Moba, to this day I still have great difficulty in detecting my own underlying cultural influences. This is mostly because I am continuously engaged in what sociologist Peter Berger $(1967,27)$ referred to as "cosmization"-the process whereby human beings intuitively deem their own culture as normative for, or at least a precise reflection of, the world as it actually is. ${ }^{4}$ In other words, I tend to consider my own cultural influences as universally normal. "Culture hides much more than it reveals and, strangely enough," says one researcher, "what it hides, it hides most effectively from its own participants" (Hall 1998, 59). Culture causes us to have blind spots. I believe the tendency to see distance learning, and particularly online learning, as somehow culturally neutral and inclusive is precisely one of these blind spots (cf. Hannon and D'Netto 2007, 419; Jung 2014, 51).

\section{An Analysis of Distance Learning and Culture}

So, what is the intersect between online learning and culture? I first encountered this question while in Africa (see Fluegge 2010). Our seminary in Togo had a rather well-developed "theological education by extension" (TEE) distance learning program in addition to our residential program. Since the rural areas of Africa we served seldom had readily available internet access, groups of participants along with their leader were to work through a series of self-guided workbooks. The reality is that the TEE program never did very well. We were never able to get it going despite a significant investment of personnel, time, and money. To this day, I believe, there is a storeroom on the seminary campus filled with thousands of dollars of dusty unused TEE books, probably by now half devoured by rats and termites. No doubt, there are a number of reasons for this program's lack of success and we should be cautious in drawing any unwarranted conclusions; however,

\footnotetext{
3 Bunkowske continued to develop the "cultural onion" throughout his life. He later described the "evaluating level" of culture as consisting of "associations, values, beliefs, and emotions" (2012).

4 Berger writes, "Every society is engaged in the never completed enterprise of building a humanly meaningful world. Cosmization implies the identification of this humanly meaningful world with the world as such, the former now being grounded in the latter, reflecting it or being derived from it in its fundamental structures" $(1967,27)$.
} 
in visiting other institutions, I realized that we were not the only seminary to confront this problem. I found similar failed programs in the seminaries of other church bodies in several other West African countries (e.g., Togo, Burkina Faso, Ghana, Ivory Coast) and in these same places centralized residential programs were faring quite well. Now, I do not mean to imply that there are no thriving distance learning theological education programs in Africa. There definitely are. Most notably, I might mention the South African Theological Seminary, a purely online seminary with students from all over Africa and the world. Nonetheless, I could not dismiss this tendency among my African comrades to favor residential centralized seminary programs-a preference which seemed to go deeper than a simple lack of familiarity with distance or online learning. Of course, we could identify any number of factors that may have contributed to this preference, some of them no doubt on a personal individual level, but I would like to focus on the cultural factor.

In the seventies and eighties, Geert Hofstede (1984) and his team of researchers identified what he called "dimensions of culture." In response to others who have critically examined his conclusions, Hofstede has further refined and bolstered his findings (Hofstede 2001; Hofstede et al., 2010). In any case, they are still considered helpful in exploring cultural influences on learning (see Wang 2007). For the purposes of this study, I want to focus on two of these dimensions: Collectivism versus individualism and high versus low power distance. To these I wish to also add what David Livermore $(2015,116-119 ; 2009,135-138)$ of the Cultural Intelligence Center and others (e.g., Gunawardena et al. 2003, 756) refer to as high-context versus low-context cultures and what I describe as oral preference versus literate preference. None of these "dimensions of culture" are meant to present an either/or situation. It is more helpful and accurate to view each as a continuum between two opposite poles with a certain culture tending to fall somewhere on the continuum, usually more toward one pole and less toward the other.

\section{Collectivism Versus Individualism}

The first cultural dimension, collectivism-individualism, is the "tendency of members of a society to act as individuals or members of groups" and the extent "to which a culture values individual or collective achievement or well-being" (Liu et al. 2010, 178). Generally speaking, European and perhaps especially Euro-American societies have traditionally favored individual achievement and uniqueness. In fact, it was a Swiss psychologist-Jean Piaget-who proposed that egocentrism was a natural part of every child's cognitive development. Since then, others (e.g., Driscoll 1994) have pointed out that his universal claims rested on observation of mostly European and some American children. Another group of researchers (Bruner et al. 1966) showed that Eskimo children display much less egocentrism than American or European children due in part to their need to work together as a group when hunting and fishing. Hofstede found that individualistic societies have an "I-consciousness" whereas collectivistic ones possess more of a "we-consciousness" (2011, 11). Hence, initiatives or activities that promote competition with the goal of individual success tend to flounder when they threaten the harmony of the whole group in collectivist societies (Westbrook 2014, 285).

Most Euro-Americans normally value individual uniqueness. Those from other cultures may value sameness. I recall a wellintentioned short-term mission team that gathered the children together from the villages they visited among the Moba people of northern Togo and presented a Bible lesson they had used for their vacation Bible school back in the United States. They taught the Moba children how God loves them so much that he made each of them unique and different from everyone else. There was no follow-up evaluation to go by, but I was unsure that the children saw that as evidence of God's love. The children enjoyed the team's visit, but from their reaction, the children did not really seem to get it.

Most African societies are community oriented and research has shown that this affects how one learns (Lephalala and Makoe 2012; Yang et al. 2010; Thompson 1998; Anakwe et al. 1999). Online learning, by its very nature of disseminating knowledge to students who live far apart, tends to be more individualistic. While it is true that great strides have been taken to create virtual learning communities, sociologists (e.g., Fukuyama 1999) tell us that such virtual communities remain fundamentally different than, for example, Moba face-to-face communities. Moba communities consist of a full network of relationships that are based on constant face-to-face contact and that touch every aspect of life, including family, work, and religion. There is little individual privacy. In the virtual community, relationships are less personal, more formal, and often long-distance (Fukuyama 1999). Individuals are not as dependent on one another and relationships are more compartmentalized. Students come together for educational purposes but do not really engage in other aspects

190 2021; 2:1 187-202 The Wabash Center Journal on Teaching

This work is licensed under a Creative Commons Attribution-NonCommercial 4.0 International License 
of each other's lives such as family, religion, and leisure activities. This means that even online virtual communities largely allow the individual to maintain his or her autonomy. Learning, even within such a virtual community, is much more individualistic than the traditional, collectivistic learning that takes place in Moba society or in many other societies throughout Africa. It is not surprising, then, that researchers find that those from individualist cultures tended to be more open to distance learning than those from more collectivist cultures (see Anakwe et al. 1999).

This is not meant to dissuade educators from using online learning when teaching students from more collectivistic cultures. Distance learning has changed and adapted as online learning technologies have continued to evolve. Perhaps even more importantly, socio-cultural tendencies have also changed and adapted to the widespread prevalence of the World Wide Web even in the farthest corners of the world. I would encourage all educators to engage in online learning but to do so with “eyes wide open" (cf. Livermore 2006), carefully considering this critically important question: How can we adjust our teaching in the online learning environment so as to engage more effectively those of our students who come from more collectivistic cultures?

\section{High Versus Low Power Distance}

The second cultural dimension, power distance, focuses on the "degree to which people accept the unequal distribution of power... in a society" (Gunawardena et al. 2003, 755). Societies that have a high power distance accept and even embrace the fact that certain individuals within those societies have greater influence and power, especially when it comes to communication. In these societies, this is a way of life endorsed and valued not only by the leaders, but also by the followers (Hofstede 2011, 9). By contrast, low power distance cultures value "leveling the playing field" and giving all individuals equal influence. We need only look at the Declaration of Independence of the United States and its opening statement on the God-given equality of all people to see that the United States is a low power distance culture. Paul Hiebert, in challenging American missionaries to examine their own cultural assumptions about equality, offers a rather jarring statement (at least, when viewed from a Euro-American perspective):

This [Euro-American] emphasis on equality seems absurd to the majority of the world's cultures, in which hierarchy is seen as the reality and the norm for all forms of life. Just as humans are higher than animals and some kinds of animals higher than others, so some kinds of humans are higher than other kinds of humans. $(1985,128)$

The egalitarian Euro-American culture of the United States contrasts rather sharply, for example, with many African societies, which are decidedly hierarchical. This is often evident in day-to-day behaviors and practices. When I began teaching at the seminary in Togo, I initially felt uncomfortable when students would run to meet me on my way to class, insist on carrying my books the rest of the way, and stand at attention when I entered the classroom. The greatest care was also taken to address others and myself with the proper titles. This contrasts rather sharply with my experience in southern California where never once as a university professor has a student carried my books to class (nor would it be expected) and where students sometimes relate to professors on a first name basis.

A glance at the history of the rise of distance education in the United States reveals that it emerged from a more progressive approach to education that is decidedly "learner-centered" rather than "teacher-reliant" (Fluegge 2010, 30-32; see also Moore 2004). This progressive approach to pedagogy was largely influenced by Deweyism, the philosophy of education expounded by John Dewey in his article "My Pedagogic Creed" at the end of the nineteenth century. Dewey writes, "the teacher is not in the school to impose certain ideas or to form certain habits in the child, but is there as a member of a community to select influences which shall affect the child and to assist him in properly responding to these influences" (1897, n.p.). In this approach, learners are responsible for constructing their own knowledge and teachers are merely "facilitators" in that process rather than "transmitters" of knowledge. This idea has dominated the distance education field since its inception (Moore 2003; see Zhang and Kenny 2010, 20). In fact, it is quite common in online education today for the subject expert to be separate from what has come to be called the course facilitator who guides the students to construct their own knowledge and understanding as they go through the course. This progressive constructivist approach to distance education often assumes a much more egalitarian relation between the student and the teacher and the communication process is much more democratic. 
Although laudable in Euro-American cultures, research indicates that this may disadvantage some from Chinese and certain African cultures that value the teacher as the giver of knowledge and the center of the learning process (Jung 2014, 18-19; Hofstede 2011, 9; see also Kang 2014). Students from these high power distance cultures tend to value feedback from the teacher more than their peers from more low power distance cultures do (Liu et al. 2010; Fang 2007; Thompson and $\mathrm{Ku} \mathrm{2005)}$ and they feel uncomfortable without the guiding presence of the teacher (Zhang and Kenny 2010). As one professor from Botswana put it: "[Our students] feel they can only learn when a teacher is teaching them" (Ojedokun n.d., 4). A Chinese student participating in a research study on this topic expressed similar sentiments: "It is like students are exploring an unknown territory in a forest. The instructor eventually comes out and leads to the right path. Because we think the teacher is an authority figure, we want to know what his thoughts are instead of discussing among ourselves blindly" (Thompson and Ku 2005, 42).

This high power distance tendency is evident in areas of the classroom outside of the teacher-student relation. We see it, for example, in the different approaches to plagiarism. My students at the seminary in Togo were often surprised when I dinged them for plagiarism. It took me a while to understand that in their eyes copying the work of an expert is to be lauded, not punished: “Altering the authority's words would be a sign of disrespect” (Jung 2014, 17). Similarly, peer evaluations can be problematic in cultures where the tasks of criticizing and assessing are reserved for those deemed to be in higher positions of authority (e.g., professor). Although team-based learning (TBL) would seem to jibe well with the group orientation of collectivistic cultures, when implementing a version of it (https://teambasedlearning.site-ym.com) in my Introduction to Pastoral Theology course with students from countries throughout West and Central Africa, I found they had a marked aversion to their teammates' peer evaluations that contributed to their final grade..$^{5}$ In their eyes, that task belonged to the professor alone. In the seminary program where I currently teach (in California) all students are required to carry out an internship during their theological and pastoral education. In addition to the evaluation filled out by their mentor pastors, we recently began requiring evaluations from other lay members of the congregation. While not a problem for any of our Euro-American students, one Chinese mentor pastor of a Chinese congregation expressed a concern. "I am concerned about this evaluation," he wrote, "because it will put [the intern] under the evaluator" (personal communication). His solution was providing a "third-party" evaluation from the senior pastor of the congregation. Since over half of our students in the seminary program come from high power distance societies, we have since decided to forego this requirement.

Again, this is not meant to discourage the use of online education among high power distance cultures. Culturally diverse learners can and have benefitted from the online classroom, even in ways that are less teacher reliant. For example, one researcher found that Chinese learners benefitted from the online discussion setting because it allowed them time to consider different answers, do the necessary research, and then formulate and edit their own responses (Zhang 2013 ). Online learning also situates the students within their own contexts where they can learn from local and more culturallysituated teachers, mentors, and elders, a benefit not necessarily found in residential education. Nevertheless, it remains important to recognize that distance education emerged from a western context and that context continues to influence its practice. The question before the responsible educator is: How can we adjust our teaching in the online learning environment so as to more effectively engage students who come from high power distance cultures?

\section{High-Versus Low-Context}

Since anthropologist Edward Hall (1976) introduced the distinction between high- and low-context cultures several decades ago, continued research has established it as an important framework for understanding cultural differences in communication patterns. So important, in fact, that one intercultural researcher has listed it as one of ten "cultural values" that a person must understand to be an effective culturally intelligent leader and communicator (Livermore 2015, 116-119).

5 This version of TBL required that each member of the team evaluate the other members for their contribution to team activities as a way of holding each other accountable. In addition to constructive feedback, the peer evaluations also contributed to the students' final grades (see, e.g., Team-based Learning Collaborative 2021).

192 2021; 2:1 187-202 The Wabash Center Journal on Teaching

This work is licensed under a Creative Commons Attribution-NonCommercial 4.0 International License 
High- versus low-context refers to the "amount of information that is implied versus stated directly in a communication message" (Gunawardena 2003, 756). Those from high-context cultures, also referred to as "indirect" cultures, tend to rely on non-verbal and indirect cues that lie outside of the verbal or textual information itself. They pay as much attention to the unspoken context as to the spoken words themselves. Even when communicating verbally they tend to favor indirectness, often using stories and proverbs that would make little sense outside of their wider context. Those from lowcontext cultures, often referred to as "direct" cultures, expect the hearer to obtain the necessary information from the code of the text itself. Nonverbal and contextual cues are ignored or considered unimportant. Low-context culture members tend to communicate in much more direct ways; they value "saying it like it is," frowning upon what they would view as beating around the bush and sugarcoating things. Direct, low-context communicators tend to view indirect communication as disingenuous, vague, and at times deceptive. Their counterparts tend to view direct communicators as blunt, rude, and at times unnecessarily aggressive. Whereas many European and Euro-American societies tend toward low-context communication, other societies like those in Mexico, China, Japan, and many throughout Africa tend to favor high-context communication patterns (Gunawardena 2003, 756; Livermore 2015, 116-119; see also Westbrook 2014, 282-283).

It makes sense that communication is more easily reduced to writing in a low-context environment than in a high-context one. This tends to make it much easier for outsiders to enter low-context societies. An abundance of written signs give clear instructions about what to do and how to think (e.g., where to cross the street, how to drive, where to eat, where to find the bathroom, where to park, why one should refrain from feeding the animals). It is much more difficult to enter high-context cultures. Unfamiliar with nonverbal contexts, the newcomer simply cannot detect as much communication.

How does this effect online learning? Writing-based online learning, largely influenced by Western approaches to communication, tends to favor individuals from low-context cultures because it inevitably isolates the verbal and written text from its wider social context (Lustig and Koester 2006). High-context cultures value that missing social context and are at a disadvantage without it. Not surprisingly, one researcher found that students from high-context cultures viewed the lack of face-to-face contact in their asynchronous classroom as a challenge to learning and forming relationships, while their low-context counterparts believed it had no impact, negative or positive, on their learning (Morse 2003). One detects here a correlation between collectivism and high-context cultures (Westbrook 2014, 285). It makes sense that the extent to which one relies on context for communication would be directly related to the value one places on embeddedness within community.

Some preliminary research indicates that the problem may not lie as much with online education, per se, as with the low-context Western models and approaches often used in online education. In a fascinating study, Cho (2010) compared the Korean social network site, Cyworld, with its American counterpart, Facebook. Although Cyworld has become quite popular in South Korea and throughout much of Asia, it recently abandoned its initiative to expand internationally due to lack of response. The Cyworld interface differs significantly from that of Facebook. Whereas Facebook features an information-heavy, text-based interface that reads like a newspaper, Cyworld users create mini avatars called "miniMes," build and decorate miniHomes in which they can live, and establish communities with other Cyworld users. These very popular networking giants have chosen two very different approaches to online social presence-one that corresponds to the collectivistic, high-context Korean culture and another that corresponds to the individualistic, low-context American culture. Another researcher analyzed McDonalds websites from high-context and low-context international cultures and found differences that, again, corresponded to their high- or low-context orientation (Würtz 2006). For example, highcontext sites tended to use more animation of people moving (such as employees bowing). She hypothesized that this may represent nonverbal communication.

Online education emerged from a Western context that favors low-context communication and individualistic values, which in turn, often affect the way we teach online. The question before the responsible educator is: How can we adjust our teaching in the online learning environment so as to engage more effectively those of our students who come from high-context cultures? 


\section{Oral Preference versus Literate Preference}

The late Professor Walter Ong, a Jesuit priest from Saint Louis University, was a forerunner in the field of research often called “orality issues." He wrote profoundly and prolifically on this topic, including The Presence of the Word (1967) in which he traces historically the shift from a primarily oral and aural mode of communication to a literate and visual mode and draws out the deep and widespread effects this has had on other aspects of cognition and life in general. His most popular book is probably Orality and Literacy: The Technologizing of the Word (1982). Both are well worth reading. Many others have since taken up his interest, including missionaries who have had first-hand experience working and teaching in societies consisting almost exclusively of oral communicators. One example is the International Orality Network (2021). ION grew out of the Lausanne Committee for World Evangelism in 2004 and is an affiliation of Christian agencies and organizations working together to make God's Word available to oral communicators in culturally appropriate ways. According to ION, oral preference individuals “communicate primarily or exclusively through oral, not textual means" (2021).

There is debate over the extent to which the technological medium (speaking or writing) affects or even determines cognition (Chandler 1995). I am probably not as much of a "technological determinist” as Ong, but my years in Togo working with those from nonliterate societies throughout West and Central Africa has convinced me that much of what Ong hypothesized is in fact true. The differences between oral and literate societies extend far beyond the ability or inability to read and write. They influence the way in which we think and learn (Ong 1982; Slack 2000; Thompson 1998; Hiebert and Hiebert Meneses 1995, 131-132, 151-154). A few surface examples might prove helpful to illustrate this point. Due to the lack of printed resources, knowledge in oral societies must be repeated to avoid being lost (Slack 2000, 10), giving rise to an emphasis on repetition in learning. This method of learning is associated with what educators sometimes refer to as "rote memorization." In oral societies, one often finds the repetitive use of songs as a particularly useful learning tool (Hiebert and Hiebert Meneses 1995, 132). Hence, Koranic schools throughout West Africa arrange their curriculum around the repetition and memorization of the Koran in Arabic, despite few adults and even fewer children actually speaking Arabic (cf. Thompson 1998). Traditional education in many West African societies relies heavily on mentoring and modeling to conserve and transmit knowledge (Thompson 1998), leading to imitation as another important instructional method. Conceptual knowledge is often preserved and remembered by housing it in stories, legends, and myths which are transmitted to the next generation (Slack 2000,12). These instructional methods (e.g., repetition, memorization, mentoring, modeling, stories) tend toward a behavioral teacher-centered approach to education rather than the more constructivist learner-centered approach that has dominated distance and online learning since its inception (Fluegge 2010).

In a study of the transfer of knowledge in West African societies, Southern Baptist missionary and linguist LaNette Thompson showed that in oral societies “knowledge's worth resides in the giver of knowledge" (1998, 3-4; cf. Hiebert and Hiebert Meneses 1995, 145). Knowledge has little validity or value apart from the one who disseminates that knowledge (i.e., teacher). It is not neutrally value ridden. In fact, many from historically oral societies in West Africa would view knowledge by itself as having no "intrinsic worth" (Thompson 1998, 3). Therefore, in many West African societies and in other oral societies around the world, education that is not closely associated with the giver of knowledge has little worth. Moreover, in many oral societies, knowledge is also valuable because it is limited and in short supply. In such a context, "knowledge is power, to be guarded and used when power is to be exhibited" (Thompson 1998, 3). Knowledge shared indiscriminately reduces its value.

This view of knowledge contrasts sharply with that of many European, Euro-American, and some Asian societies, for example, where the printed book disseminates knowledge haphazardly and inevitably creates a permanent disconnect between the giver of knowledge and its recipient. Perhaps even more problematic, online learning has traditionally separated and compartmentalized the education process into its constituent parts-the "subject expert" is different from the "course designer" who is different from the "course facilitator" who interacts with the students often only through a written medium (Fluegge 2010).

It seems inevitable that writing-based approaches to distance online learning are prone to hinder oral preference learners. The question before the responsible educator is: How can we adjust our teaching in the online learning environment so as to engage more effectively those of our students who come from more oral cultures?

194 2021; 2:1 187-202 The Wabash Center Journal on Teaching

This work is licensed under a Creative Commons Attribution-NonCommercial 4.0 International License 


\section{Concluding Practical Suggestions}

Many models already exist to help the educator design an intercultural and culturally responsive online course (e.g., Young 2009; Stephan and Stephan 2013). My intention here is not to delve into the abundance of literature on this topic, but rather to offer a few practical suggestions for how theological educators might begin adjusting their online classrooms and programs to account for the cultural dimensions explored above and more effectively engage diverse learners. The hope is that these will, in turn, serve as an impetus for continued research and exploration of more culturally responsive online learning practices.

First there is an underlying principle to consider. One's approach affects one's attitude which, in turn, affects the outcome. Homiletics professor Lisa Lamb from Fuller Theological Seminary advises that it is ultimately unhelpful to approach the diverse classroom as made up of students who possess a "set of challenges" that must be overcome (2019, 94). Such a "deficit pedagogy" that views students from certain cultures as inherently disadvantaged would seem to only perpetuate cultural hegemony and ultimately lead to further alienation. An "asset pedagogy," on the other hand, views the unique cultural traits of the diverse classroom as advantages. Such an approach leads the educator to adopt teaching methodologies that not only engage but also affirm the cultural values of diverse learners. Here are a few suggestions:

- Train faculty and staff in "cultural intelligence” (CQ) to create an environment that is intentionally and willingly responsive to cultural differences (cf. Westbrook 2014, 292). The learner support staff should be as culturally aware as the faculty. See, for example, the Cultural Intelligence Center (https://culturalq.com/), which offers researchbased tools, training seminars, and helpful assessments. The Cultural Intelligence Center has partnered with faithbased churches and organizations, but also with businesses (e.g., Starbucks, McDonalds) and with universities (e.g., University of Michigan) to help participants develop cultural intelligence by going beyond mere knowledge and translating that knowledge into culturally aware and responsive action. This is only one among an array of other training resources.

- $\quad$ Strive to communicate with students in multiple ways-email, online chat, phone, and especially online videoabout course content, but also regarding important course requirements, expectations, and guidelines. As a decidedly low-context professor, I have to admit a certain amount of frustration and even exasperation when students have repeatedly asked questions about course expectations that seem, at least to me, to be clearly covered in the syllabus. Yet theology professor Timothy Westbrook of the Center for Distance Education in Bible and Ministry at Harding University suggests that we might reconsider whether the low-context written syllabus is always an adequate means of communicating course expectations: "Instead, the low-context professor following Christ's incarnational model might recognize the limitations of low-context communication and find high-context ways to inform students from different backgrounds" (Westbrook 2014, 289-290). Online video apps such as Zoom, Facetime, or WhatsApp tend to be more high context than the written medium of the syllabus.

- Create assignments early in the course with the express goal of building up community and social presence. Although this may be considered an online best practice in general, it is of paramount importance for learners from collectivistic, high-context cultures that tend to view life holistically. As a task-oriented American, it took me a while when we first arrived in Togo to learn the value of the prolonged traditional Moba greetings inquiring about the previous night's sleep, the wife, the children, the household, the village, the crops, the livestock, and so forth. I soon realized that this ritual was more than a mere nicety. It laid the foundation for more authentic communication. My experience in Togo parallels that of Melinda Thompson and Meri MacLeod of Abilene Christian University when they first began interacting with West African Ghanaian students in their online Master's program. The students' written correspondence often included rather lengthy greetings and inquiries about family and health that seemingly had little to do with the content of the course. Yet viewed from a more holistic perspective, they had everything to do with the course. And they were much more than just common courtesies. "While these introductory items seemed superfluous to the American recipients-possibly even intrusive into one's personal life-they formed the backbone of relationship building for the Ghanaian students" (Thompson and MacLeod 2015, 121). Community building and social presence are of paramount importance in the online diverse classroom. It may be helpful, for example, to give an initial discussion board assignment asking students to introduce themselves 
in some detail, if they so desire, and then have them respond to pointed questions that give them opportunity to share background cultural information for the purposes of building up the classroom community (Woodley et al. 2017, 472-473).

- For similar reasons, many educators suggest making use of online classroom/meeting software for regular synchronous online class sessions throughout the course or, at least, early in the term (Woodley et al. 2017, 475476; Uzuner 2009, 12; Westbrook 2014, 292; Fluegge 2010, 41; cf. Lamb 2019, 100). This real-time connection can help establish social presence. In our online seminary program, students "go to class" together via Zoom where they can see each other and communicate in real time via mic, chat, or other signals (e.g., raise hand) and emojis. I am always encouraged to see students from such a wide diversity of backgrounds using the chat bar before class to greet one another and inquire about personal matters, and when I see the Hispanic and Anglo students bantering good-naturedly in Spanish. I am not suggesting that synchronous live video is superior to asynchronous activities such as discussion forums. Each has its place and its advantages and disadvantages. However, I would suggest that gathering together online can provide a foundation for more effective asynchronous work later on, especially in the culturally-diverse classroom. If synchronous live video class sessions are not possible, another idea is to schedule a phone call with each student early in the term. The point is to establish a real-time connection. Some institutions may require that an entire degree be possible to achieve asynchronously. In these cases, one could give students the option of connecting synchronously or submitting an equivalent written assignment (Lamb 2019, 100).

- If possible, design required times of face-to-face community building into the program curriculum at regular intervals (Fluegge 2010, 41; Uzuner 2009, 12). This may already be a common best practice in many online programs, but I emphasize it here for two reasons. First, students from more collectivistic, high-context, and oral cultures may find this helpful for cultural reasons, not just because of personal learning preferences. Secondly, the goal of these face-to-face gatherings ought to go beyond classroom learning and purposefully include in-person community building. Few programs are better suited to do this than the seminary program-specifically designed as it is to train spiritual, as well as theological, leaders for the church. This common desire to shape the heart (spiritual) as well as the head (theological) would seem to provide a fitting context for building up authentic camaraderie. We have found, for example, that integrating required three-week "Summer Community Gatherings" into the curriculum of our seminary program has given rise to a marked increase in our students' sense of close community, and all the more so because of the wide diversity of cultures represented. These gatherings are much more than opportunities to attend intensive face-to-face classes. A coordinator plans corporate activities that intentionally bridge cultures and build community. Students attend chapel services and worship together, pray together, share meals together, and share life together in the dorms.

- Design ways for students to pray for and spiritually care for one another in and out of class. My own tendency is to compartmentalize my life. I normally expect academic classes to occupy one part of my life and assign spiritual care to another. Some of this seems to come from my tendency towards a more individualistic approach to life. What would it look like to bring them together in a more collectivistic way? The seminary program context provides a unique opportunity to do precisely this. One homiletics professor has her students post an introductory video the first week of class and encourages them to share a prayer request if they are comfortable doing so (Lamb 2019 , 100). In our seminary program we make a concerted effort to share individual prayer requests regularly with the wider online community via email and a bi-monthly newsletter. During our face-to-face summer gatherings, we have a formal ritual-a sending ceremony-during which we pray over those who will be graduating during the coming year and send them into the mission field where they will be called to carry out their ministries. Formal and informal rituals are often neglected in the online environment due to lack of proximity, but also due to the spirit of anti-ritualism that influences much of American culture (Kleinig 1998).6 This is unfortunate because formal rituals are essential in some cultures that have a strong collectivistic and oral approach to life. For this reason, the sending ceremony has become an expected part of our summer face-to-face gatherings. We close the sending

6 Kleinig (1998) gives an intriguing description of his experiences teaching and interacting with the Australian Aborigines who deeply value ritual. The Aborigines are an example of a primarily oral, collectivistic culture.

196 2021; 2:1 187-202 The Wabash Center Journal on Teaching

This work is licensed under a Creative Commons Attribution-NonCommercial 4.0 International License 
ceremony with a prolonged time of prayer over each graduating student and then over each other as we gather together afterwards. Students have expressed how meaningful this event is for them. Many reasons could be cited. One could make a theological case for the need to pray together but there is also a cultural case to be made. For students coming from collectivistic cultures, the ceremony breaks down the artificial compartmentalization of our academic and spiritual lives.

- Collaborate with local churches so that students serve as interns under the mentorship of well-trained role models or mentors. This has long been considered a best practice, even in face-to-face programs. But, for logistical reasons, classroom learning is most often separated from the internship experience, thus reinforcing in the student's mind an artificial separation between theory and practice. The online classroom can avoid this tendency by leveraging one of its distinct advantages-learning is situated or embedded in a natural, communal, local context rather than the artificial environment of the face-to-face classroom. One way to fully leverage this advantage is to require that students serve as interns while they are taking courses throughout the entire program. Many online seminary programs already do this, regardless of the cultural makeup of their students. I mention it here as a culturally responsive best practice, however, because of its potential to especially benefit learners from more collectivistic, high-context, high power, oral cultures. Such cultures tend to place great value on role modeling and mentoring as key elements in the learning process, much more so than other cultures. Moreover, interns placed in their own cultural milieu benefit from learning at the feet of respected leaders, mentors, and elders from their respective cultures, even as they continue learning from their classes. In fact, to fully maximize the distinct advantage of online "embedded" learning, one ought to increase the overlap and interaction between academic courses and the practical internship experience (whether formal or informal). In the face-to-face classroom, this interaction is often imagined: "How would you respond to a church member who says that the ecumenical creeds are oldfashioned statements with little value for the Christian today?" In the online classroom the interaction can go beyond simulation to engage real life ministry: "Interview and interact with two people from your church about their thoughts regarding the use and value of the ecumenical creeds today. Summarize your conversation with each of them and explain how you were able to emphasize the enduring importance and value of the ancient creeds." The simulated environment of the face-to-face classroom can sometimes prove to be a hindrance especially for the culturally diverse student. I recall one African American student struggling to preach in front of the class during a face-to-face homiletics course. He seemed to falter and lose momentum, struggling to smoothly transition from one point to another. In conversations afterwards, we discovered the problem-the lack of interactive responses from the audience was throwing the student off his game. He was used to preaching to an African American congregation where vocal responses and physical reactions to the sermon were not just normal, but an expected dynamic. One homiletics professor at Fuller Theological Seminary not only allows but requires students to preach sermons in a local context, preferably in their own congregations. Sermons are evaluated by several members of the congregation, while a recording is evaluated by the professor and other students in class. She remarks, "I have been struck by the way Puerto Ricans sound more like Puerto Ricans, and African Americans sound more like African Americans" (Lamb 2019, 93).

- Consider adjusting teaching methods to reach oral communicators more effectively. This includes the use of "contextual Bible storying." Training seminars are available through such organizations as Living Water International (https://www.water.cc/orality) and the International Orality Network (https://orality.net/events/). Here is an example to whet the appetite. During the last few terms, I have experimented with "storying” in my basic theology course and have been pleasantly surprised at the results. During a synchronous live video class session on Law and Gospel, I ask students to close their Bibles while I tell (not read) the story of "Jesus and the Rich Young Ruler" (Luke 18:18-27). I tell it four times7 before placing students in online groups to respond to four questions: (1) What did Jesus say that made the rich man very sad? (2) Why do you think Jesus said this to him? (3) What did Jesus say to those who asked him afterwards, "Then who can be saved?" (4) Why does Jesus reply differently to those afterwards than to the rich man? I am always amazed at the depth of our ensuing discussion, especially as they wrestle with that final question and what it says about "Law and Gospel." Although not the case for every student, the oral telling of the story helps many students to concentrate more effectively on its details and reflect more

7 Another option before moving on with the exercise is to have one or two students retell the story back to the rest of the class. 
deeply about its meaning. Oral learners favor hearing rather than reading. For this reason, educators of diverse classrooms might consider integrating the option of using cell phones as an oral means, for example, to memorize the Greek alphabet/vocabulary and to listen to the professor's feedback (Thompson and MacLeod 2015, 120).

- Finally, ensure that students clearly understand what constitutes plagiarism. Many graduate level seminary programs make this information available to students and inform them about the use of plagiarism detection tools. But this is more of a passive approach. For the culturally-diverse program, a more active approach would be helpful in preventing future misunderstandings and disappointment on the part of student and professor alike. One suggestion is to have students complete an assignment early in the course (or program) in which they identify various kinds of plagiarism. Throughout, students should be encouraged to borrow and build on the ideas of others as long as they honor the giver of knowledge with a proper citation.

\section{Conclusion}

It is perhaps fitting to conclude with a few disclaimers. This essay has inevitably dealt with generalities. That is the nature of studying cultures and it can be one of the challenges of doing so. We know from research that culture does influence the learning process and its outcomes, but this reality is delimited by two factors that must also be kept in mind (see Gunawardena et al. 2003, 764). On the one side, universal principles of learning common to all human beings do exist across all cultures and pedagogical decisions should build on these principles. On the other side, individuals also have unique learning style preferences. It is important to avoid the fallacies of homogeneity and monolithic identity, whereby we ignore the individual differences among members of a cultural group and assume there are no "differential identities" (e.g., Gunawardena et al. 2003, 771). It is also true that limiting learning activities and assessment choices may helpfully push "students to expand their learning comfort zones and to successfully process information and acquire skills in a variety of formats" (Gunawarden et al 2003, 768).

Moreover, the increasingly multicultural and intercultural reality of the United States and our own classrooms is not neat and tidy like we might want it to be. "Culture is dynamic and ever changing" (Jung 2014, 18). Students immigrating to the United States accommodate and assimilate. The children of those immigrants-the second generation-have feet in both worlds. Some, such as the prescient Walter Ong (1982), have even hypothesized that the rise of radio and television and more recently computer technologies, digital/audio books, and especially smart phones has generally given rise to certain "post-literate" oral tendencies on a wide scale in the West. In short, detecting cultural influences and adapting accordingly is often a complex and difficult undertaking. Nonetheless, as professors and educators, ignoring the cultural dimension and its influence on our online teaching practices is far more perilous, especially in light of the increasingly multicultural milieu in which we now live and work.

\section{B I B LIOGRAPHY}

Anakwe, Uzoamaka P., Eric H. Kessler, and Edward W. Christensen. 1999. "Distance Learning and Cultural Diversity: Potential Users' Perspective.” The International Journal of Organizational Analysis 7, no. 3: 224-243. https://doi. org/10.1108/ebo28901.

Arkorful, Valentina, and Nelly Abaidoo. 2015. "The Role Of E-Learning, Advantages and Disadvantages of its Adoption in Higher Education.” International Journal of Instructional Technology and Distance Learning 12, no. 1 (January): 29-42. http://itdl.org/Journal/Jan 15/Jan15.pdf\#page=33.

Berger, Peter L. 1967. The Sacred Canopy: Elements of a Sociological Theory of Religion. New York, NY: Anchor Books.

Bettinger, E., and S. Loeb. 2017. "Promises and Pitfalls of Online Education.” Brookings Institute Evidence Speaks Reports 2, no. 15 (June 9). https://www.brookings.edu/research/promises-and-pitfalls-of-online-education/.

Bruner, J. S., R. R. Oliver, and P. M. Greenfield. 1966. Studies in Cognitive Growth. New York, NY: Wiley.

198 2021; 2:1 187-202 The Wabash Center Journal on Teaching

This work is licensed under a Creative Commons Attribution-NonCommercial 4.0 International License 
Bunkowske, Eugene W. 2002. “The Cultural Onion.” Course Handout, THY 573: Outreach Ministry in Context. Concordia Theological Seminary, Ft. Wayne, IN. https://docslide.net/documents/the-culture-onion.html.

Bunkowske, Eugene W. 2012. “The Transformation Journey: An Example to Consider.” In Missional Transformation: God's Spirit at Work, ed. Mark G. Press and Eugene W. Bunkowske, 302-321. Bloomington, IN: Author House.

Chandler, Daniel. 1995. "Biases of the Ear and Eye: 'Great Divide’ Theories, Phonocentrism, Graphocentrism, and Logocentrism.” Media and Communications Site. http://www.aber.ac.uk/media/Documents/litoral/litoral.html.

Cho, S. E. 2010. "A Cross-Cultural Comparison of Korean and American Social Network Sites: Exploring Cultural Differences in Social Relationships and Self-Presentation." Unpublished doctoral dissertation, Rutgers University, New Brunswick, NJ.

Cole, Michael, and Sylvia Scribner. 1974. Culture and Thought: A Psychological Introduction. London, UK: John Wiley and Sons.

Dewey, John. 1897. “My Pedagogic Creed.” The School Journal 54, no. 3 (16 January): 77-80. http://dewey.pragmatism. org/creed.htm.

Driscoll, M. P. 1994. Psychology of Learning for Instruction. Boston, MA: Allyn and Bacon.

Dynarski, Susan. 2018. “Online Courses Are Harming the Students Who Need the Most Help.” New York Times, January 19. https://www.nytimes.com/2018/01/19/business/online-courses-are-harming-the-students-who-need-themost-help.html.

Edmundson, Andrea, ed. 2007. Globalized E-Learning Cultural Challenges. Hershey, PA: Information Science Publishing.

Elmer, Duane. 1993. Cross-Cultural Conflict: Building Relationships for Effective Ministry. Downers Grove, IL: InterVarsity Press.

Fain, Paul. 2019. “Takedown of Online Education.” Inside Higher Education (January 16). https://www.insidehighered. com/digital-learning/article/2019/01/16/online-learning-fails-deliver-finds-report-aimed-discouraging.

Fang, L. 2007. "Perceiving the Useful, Enjoyable, and Effective: A Case Study of the E-Learning Experience of Tertiary Students in Singapore." Educational Media International 44, no. 3: 237-253. https://doi. org/10.1080/09523980701491682.

Fluegge, Glenn. 2010. "A Historical and Socio-Cultural Analysis of Distance Education in the United States with Implications for Distance Theological Education in Africa." Journal of Adult Theological Education 7, no. 1: $26-43$. https://doi.org/10.1558/iate.v7i1.26.

Fukuyama, Francis. 1999. “The Great Disruption.” The Atlantic Monthly 283, no. 5: 55-80.

Gunawardena, Charlotte N., Penne L. Wilson, and Ana C. Nolla. 2003. “Culture and Online Education.” In Handbook of Distance Education, ed. Michael G. Moore and William G. Anderson, 753-775. London, UK: Lawrence Erlbaum.

Hall, Edward T. 1976. Beyond Culture. Garden City, NY: Anchor Press/Doubleday.

Hall, Edward T. 1998. “The Power of Hidden Differences.” In Basic Concepts of Intercultural Communication: Selected Readings, ed. M. J. Bennett, 53-67. Yarmouth, ME: Intercultural Press.

Hannon, John, and Brian D’Netto. 2007. “Cultural Diversity Online: Student Engagement with Learning Technologies.” International Journal of Educational Management 21, no. 5: 418-432. https://doi. org/10.1108/09513540710760192. 
Hiebert, Paul G. 1985. Anthropological Insights for Missionaries. Grand Rapids, MI: Baker Book House.

Hiebert, Paul, and Hiebert Meneses, Eloise. 1995. Incarnational Ministry: Planting Churches in Band, Tribal, Peasant, and Urban Societies. Grand Rapids, MI: Baker Books.

Hofstede, Geert. 1984. Culture's Consequences: International Differences in Work-Related Values (2nd ed.). Beverly Hills, CA: Sage Publications.

Hofstede, Geert. 2001. Culture's Consequences: Comparing Values, Behaviors, Institutions, and Organizations across Nations. Thousand Oaks, CA: Sage Publications.

Hofstede, Geert. 2011. “Dimensionalizing Cultures: The Hofstede Model in Context.” Online Readings in Psychology and Culture 2, no. 1. https://scholarworks.gvsu.edu/orpc/vol2/iss1/8/.

Hofstede, G., G. J. Hofstede, and M. Minkov. 2010. Cultures and Organizations: Software of the Mind (3rd ed.). New York, NY: McGraw-Hill.

Horodyskyj, L. B., C. Mead, Z. Belinson, S. Buxner, S. Semken, and A. D. Anbar. 2018. “Habitable Worlds: Delivering on the Promises of Online Education.” Astrobiology 18, no. 1 (January): 86-99. https://www.liebertpub.com/doi/ abs/10.1089/ast.2016.1550.

International Orality Network. 2021. International Orality Network. https://orality.net/.

Jung, Insung. 2014. “Cultural Influences on Online Learning.” In Culture and Online Learning, ed. Insung Jung and Charlotte Gunawardena, 15-24. Sterling, VA: Stylus Publishing.

Kang, Haijun. 2014. “Understanding Online Learning Across Cultures: The Encounter Between Confucius Culture and Western Culture." In Proceedings of the Seventh Asian Diaspora Pre-Conference, ed. Q. Sun, 44-56. https://krex.kstate.edu/dspace/handle/2097/18738.

Kleinig, John. 1988. “Witting or Unwitting Ritualists.” Lutheran Theological Journal 22, no. 1: 13-22. https://www. doxologv.us/wp-content/uploads/2015/03/58 Witting-or-Unwitting-Ritualists-bv-John-Kleinig.pdf.

Lamb, Lisa. 2019. “Enabling Diverse Learners to Thrive in the Online Homiletics Classroom.” Teaching Theology and Religion 22, no. 2: 92-101. https://doi.org/10.1111/teth.12476.

Lephalala, Mirriam M., and Mpine Makoe. 2012. "The Impact of Socio-Cultural Issues for African Students in the South African Distance Education Context.” International Journal of E-Learning and Distance Education 26, no. 1. http: // www.ijede.ca/index.php/ide/article/view/759/1320

Livermore, David. 2006. Serving with Eyes Wide Open: Doing Short-Term Missions with Cultural Intelligence. Grand Rapids, MI: Baker.

Livermore, David. 2009. Cultural Intelligence: Improving Your CQ to Engage Our Multicultural World. Grand Rapids, MI: Baker Academic.

Livermore, David. 2015. Leading with Cultural Intelligence: The Real Secret to Success. New York, NY: Amacom.

Liu, Xiaojing, Shijuan Liu, Seung-hee Lee, and Richard J. Maguka. 2010. "Cultural Differences in Online Learning: International Student Perceptions." Educational Technology and Society 13, no. 3: 177-188. http://citeseerx.ist. psu.edu/viewdoc/summary?doi=10.1.1.174.1119.

Lustig, M. W., and Koester, J. 2006. Intercultural Competence: Interpersonal Communication Across Cultures. New York, NY: Pearson.

200 2021; 2:1 187-202 The Wabash Center Journal on Teaching

This work is licensed under a Creative Commons Attribution-NonCommercial 4.0 International License 
Mercado, Simon, K. Praveen Parboteeah, and Yushan Zhao. 2004. "On-line Course Design and Delivery: Cross-National Considerations." Strategic Change 13, no. 4:183-192. https://doi.org/10.1002/isc.677.

Moore, Michael. 2003. From Chautauqua to the Virtual University: A Century of Distance Education in the United States. Canadian Journal for the Study of Adult Education 18, no. 1: 96-98. https://cjsae.library.dal.ca/index.php/ cjsae/article/view/1849.

Moore, Michael. 2004. “Debate Response." Open Learning: The Journal of Open, Distance, and e-Learning 19, no. 3 (November): 319-328. https://doi.org/10.1080/0268051042000280174.

Morse, K. 2003. “Does One Size Fit All? Exploring Asynchronous Learning in a Multicultural Environment." Journal of Asynchronous Learning Networks 7, no. 1: 37-55. https://olj.onlinelearningconsortium.org/index.php/oli/article/ view/1862.

Ojedokun, Ayoku A. n.d. Distance Education and the New Information and Communications Technologies: An Analysis of Problems Facing a Developing Country. https://www.academia.edu/5070898/distance education and the new information and communications technologies an analysis of problems facing a developing country (accessed Sept 30, 2019).

Ong, Walter J. 1967. The Presence of the Word: Some Prolegomena for Cultural and Religious History. Minneapolis, MN: University of Minnesota Press.

Ong, Walter J. 1982. Orality and Literacy: The Technologizing of the Word. London, UK: Methuen and Co.

Slack, James B. 2000. "A Paper for Telling or Reading: The International Mission Board, SVC Faces Issues Related to Orality, Literacy, and Oral (Non-Print) Communicators and Oral Communication." Paper delivered at the MultiAgency Non-Print Media Consultation in Nairobi, Kenya, June.

Stephan, Walter G., and Cookie White Stephan. 2013. "Designing Intercultural Education and Training Programs: An Evidence-Based Approach." International Journal of Intercultural Relations 37, 277-286. https://doi.org/10.1016/i. iiintrel.2012.05.001.

Team-based Learning Collaborative (TBLC). 2021. “Getting Started with TBL.” https://teambasedlearning.site-ym.com/ page/started.

Thompson, LaNette W. 1998. “The Nonliterate and the Transfer of Knowledge in West Africa." Master's thesis, The University of Texas, Arlington, TX.

Thompson, L., and Ku, H. 2005. “Chinese Graduate Students' Experiences and Attitudes toward Online Learning." Educational Media International 42, no. 1: 33-47. https://doi.org/10.1080/09523980500116878.

Thompson, Melinda, and Macleod, Meri. 2015. "To the Ends of the Earth: Cultural Considerations for Global Online Theological Education." Theological Education 49, no. 2: 113-125. https://www.ats.edu/uploads/resources/ publications-presentations/theological-education/2015-theological-education-v49-n2.pdf\#page=127.

Uzuner, Sedef. 2009. "Question of Culture in Distance Learning: A Research Review." International Review of Research in Open and Distance Learning 10, no. 3: 1-19. http://www.irrodl.org/index.php/irrodl/article/view/690/1273.

Wang, M. 2007. "Designing Online Courses that Effectively Engage Learners from Diverse Cultural Backgrounds." British Journal of Educational Technology 38, no. 2: 294-311. https://bera-journals.onlinelibrary.wiley.com/doi/ abs/10.1111/i.1467-8535.2006.00626.x.

Westbrook, Timothy P. 2014. "Global Contexts for Learning: Exploring the Relationship between Low-Context Online Learning and High-Context Learners." Christian Higher Education 13, no. 4: 281-294. https://doi.org/10.1080/153 $\underline{63759.2014 .924888 .}$. 
Woodley, Xeturah, Hernandez, Cecilia, Parra, Julia, and Negash, Beyan. 2017. “Celebrating Difference: Best Practices in Culturally Responsive Teaching Online.” Tech Trends 61, 470-478. https://link.springer.com/article/10.1007/ S11528-017-0207-Z.

Yang, Dazhi, Larissa Olesova, and Jennifer C. Richardson. 2010. “Impact of Cultural Differences on Students' Participation, Communication, and Learning in an Online Environment." Journal of Educational Computing Research 43, no. 2: 165-182. https://doi.org/10.2190/EC.43.2.b.

Young, Patricia A. 2009. Instructional Design Frameworks and Intercultural Models. New York, NY: Information Science Reference.

Zhang, Yi. 2013. "Power Distance in Online Learning: Experience of Chinese Learners in U.S. Higher Education.” International Review of Research in Open and Distance Learning 14, no. 4: 238-254. http://www.irrodl.org/index. $\mathrm{php/irrodl/article/view/1557.}$

Zhang, Z., and Kenny, R. 2010. “Learning in an Online Distance Education Course: Experiences of Three International Students." International Review of Research in Open and Distance Learning 11, no. 1: 17-36. https://pdfs. semanticscholar.org/9542/e5c9egoegf538757eee3bff22757e37baf54.pdf.

\section{ABOUT THE AUTHOR}

Glenn Fluegge currently serves as professor of theology at Concordia University Irvine in southern California and also director of the Cross-cultural Ministry Center, a seminary program that forms missionary pastors for culture-crossing ministries in the United States and throughout the world. Previously, he served for fourteen years as lecturer and director of the Centre Luthérien d'Etudes Théologiques, an international seminary in Togo, West Africa, and as lecturer at the Lutheran Theological Seminary in South Africa. 